\title{
Morfometri Limpa Berkaitan dengan Produksi Radikal Bebas dan Antioksidan pada Kelelawar Pemakan Buah Codot Krawar (Cynopterus brachyotis)
}

\author{
(MORPHOMETRIC STUDY OF SPLEEN ASSOCIATED WITH \\ FREE RADICAL PRODUCTION AND ANTIOXIDANT DEFENSE \\ IN THE LESSER SHORT-NOSED FRUIT BATS (Cynopterus brachyotis)) \\ Desrayni Hanadhita ${ }^{1}$, Andhika Yudha Prawira ${ }^{2}$, Anisa Rahma ${ }^{1}$, \\ Aryani Sismin Satyaningtijas ${ }^{1}$, Srihadi Agungpriyono ${ }^{2}$ \\ ${ }^{1}$ Laboratorium Fisiologi, ${ }^{2}$ Laboratorium Anatomi \\ Departemen Anatomi, Fisiologi, dan Farmakologi, \\ Fakultas Kedokteran Hewan, Institut Pertanian Bogor, \\ Jl. Agatis Kampus IPB Dramaga, Bogor, Jawa Barat, Indonesia, 16680 \\ Tel +62 251 8629469, 8629464, Fax +62 251 8629464, Email: ysrihadi@aspps,ipb.ac.id
}

\begin{abstract}
ABSTRAK
Kelelawar pemakan buah merupakan reservoir alami banyak penyakit zoonosis yang saat ini bermunculan. Kelelawar yang terinfeksi tidak menunjukkan gejala klinis dan dapat terinfeksi secara persisten. Karakter unik kelelawar mengindikasikan kelelawar memiliki aktivitas kekebalan yang tinggi untuk pertahan terhadap virus walaupun dalam keadaan fisiologis. Aktivitas kekebalan yang tinggi dapat memengaruhi ukuran organ limfoid secara umum dan berakibat pada produksi reactive oxygen species (ROS). Limpa merupakan salah satu organ limfoid terpenting yang memiliki fungsi strategis dalam eliminasi patogen dalam darah, Penelitan ini dilakukan untuk menyediakan data mengenai ukuran normal limpa serta menganalisis kadar malonaldehyde (MDA) dan super oxide dismutase (SOD) pada kelelawar pemakan buah liar Cynopterus brachyotis. Rasio bobot limpa terhadap bobot badan kelelawar C. brachyotis adalah $0,4 \%$ dan tidak ada perbedaan signifikan antara jantan dan betina. Kadar MDA limpa, yang menggambarkan produksi ROS lebih tinggi dibandingkan kadar MDA hati. Jantan dengan kadar MDA lebih tinggi memiliki ukuran limpa yang lebih besar dibandingkan betina dengan kadar MDA lebih rendah. Kadar ROS yang tinggi diketahui berdampak negatif terhadap materi genetik, namun pada kelelawar hal ini mendukung pertahanan tubuh kelelawar sebagai reservoir virus. Kadar MDA yang tinggi secara umum disertai dengan tingginya kadar SOD yang dapat menurunkan efek negatif stres oksidatif pada C. brachyotis.
\end{abstract}

Kata-kata kunci: Chiroptera; ekofisiologi; mamalia terbang; morfologi; stres oksidatif

\begin{abstract}
Fruit bats have been reported as the natural reservoir of many emerging and re-emerging zoonotic diseases. Infected bats usually do not show any clinical symptoms and are infected persistently. This unique characters indicate that bats have high immune activity to combat viruses even in its physiological state. High immune activity will affect the size of lymphoid organ and produce high level of reactive oxygen species (ROS). Spleen is one of the important lymphoid organ which have a strategic function in elimination of blood borne pathogens. This study was undertaken to provide information on the normal size of spleen and to analyze malonaldehyde (MDA) and super oxide dismutase (SOD) levels of free range fruit bats (Cynopterus brachyotis). The ratio of body weight/spleen was $0.4 \%$ and there were no significance differences between the male and female bats. The spleen MDA levels which represent ROS generation was higher than those of the liver. Male bats with higher levels of MDA tend to have bigger spleen size than the female which has lower MDA levels. High levels of MDA might indicate a high immune activity inside the spleen. Despite the negative effect of ROS to genetic material, high level of ROS can be advantageous to support the bats immune system as a viral reservoir. High levels of MDA are generally accompanied by high levels of SOD which might reduce the negative impact of oxidative stress in the C. brachyotis.
\end{abstract}

Keywords: Chiroptera; ecophysiology; flying mammal; morphology; oxidative stress 


\section{PENDAHULUAN}

Kelelawar pemakan buah menarik perhatian peneliti karena dilaporkan berperan sebagai reservoir virus zoonotik yang saat ini bermunculan seperti sudden acute respiratory syndrome-like coronavirus; Ebola dan Marburg hemorrhagic fever filovirus, rabies dan lyssavirus yang berkaitan dengan rabies; serta banyak paramyxovirus termasuk rubulavirus, Nipah, dan Hendra (Calisher et al., 2006; Smith dan Wang, 2013; Schountz 2014; O'Shea et al., 2014; Damayanti dan Sendow, 2015; Han et al., 2015). Kelelawar pemakan buah memiliki peran strategis dalam penyebaran berbagai penyakit yang dibawanya. Perilaku memakan buah menjadi kunci penyebaran virus antar spesies. Kelelawar tidak dapat menelan makanan dalam jumlah besar sehingga hanya mengunyah buah yang dimakannya dan memuntahkannya. Kunyahan buah yang terkontaminasi oleh saliva kelelawar tersebut dan juga ekskretanya dapat mengontaminasi hewan domestik yang rentan terhadap virus dan kemudian terinfeksi. Hewan domestik yang terinfeksi dapat menjadi inang antara virus dan menularkannya ke manusia (Dobson 2005). Kelelawar juga dapat berkontak langsung dengan manusia yang juga menjadi sarana penularan virus yang dibawa oleh kelelawar (Messengger et al., 2002).

Kelelawar pemakan buah yang umum dijumpai di pemukiman penduduk Indonesia khususnya di Pulau Jawa adalah Eonycteris, Pteropus, Rousettus, dan Cynopterus (Suyanto 2011). Genus Cynopterus sering dijumpai di area pemukiman penduduk khususnya di Jawa Barat. Beberapa virus telah diisolasi dari Cynopterus yaitu virus-virus yang termasuk genus Flavivirus antara lain Carey Island virus, Jugra virus, Kyasanur Forest disease virus, Phonm-Penh bat virus, dan Keterah virus (Calisher et al., 2006). Berdasarkan data yang dihimpun oleh Bhatnagar (2013), status konservasi semua spesies Cynopterus di Asia Tenggara dalam International Union for Conservation of Nature (IUCN) adalah risiko rendah (low risk), oleh karena itu kelelawar genus Cynopterus dapat dieksplorasi secara mendalam untuk memahami morfologi dan fisiologi kelelawar pemakan buah secara umum.

Penelitian komparatif yang dilakukan Luis et al. (2013) melaporkan bahwa virus zoonotik lebih banyak menginfeksi kelelawar per spesies dibandingkan rodensia, walaupun jumlah spesies rodensia dua kali lebih banyak dari kelelawar. Kelelawar yang terinfeksi virus seringkali tidak menunjukkan gejala klinis dan pada beberapa kasus dapat terinfeksi secara laten (Baker et al., 2012). Keunikan pertahanan tubuh kelelawar terhadap virus berkaitan dengan perannya sebagai reservoir virus menjadi hal yang menarik untuk dipelajari lebih dalam. Pengungkapan aspek kekebalan pada kelelawar didominasi oleh kajian-kajian molekular yang menyediakan data yang luas untuk memahami ketahanan kelelawar terhadap virus. Namun, hingga saat ini belum ada kajian mengenai morfofisiologi organ kekebalan (limfoid) kelelawar dan komponennya secara mendalam. Salah satu organ limfoid yang penting dalam kekebalan tubuh adalah limpa. Limpa merupakan organ limfoid terbesar pada mamalia, dan tidak hanya memiliki peran penting dalam sistem kekebalan dan hematopoiesis individu namun juga dalam penyaringan darah, pembersih sel-sel yang tua dan rusak, serta reservoir platelet dan darah. Peranan limpa dalam penyaringan antigen blood borne membuat limpa menjadi organ penting pada individu (Brendolan et al., 2007). Limpa memiliki peranan penting dalam pertahanan tubuh terhadap virus karena limpa merupakan situs maturasi komponen kekebalan bawaan dan dapatan yang dapat mengeliminasi virus (Bronte dan Pittet, 2013).

Penelitian ini merupakan penelitian tahap pertama dari rangkaian penelitian kajian morfofisiologi limpa kelelawar pemakan buah. Penelitian tahap pertama ini mencakup analisis dan dokumentasi ukuran limpa kelelawar pemakan buah serta pengajian profil stres oksidatif pada organ limpa kelelawar yang dikaitkan dengan fungsi fisiologis kekebalan dan morfologi limpa. Pengetahuan terhadap ukuran limpa suatu spesies dalam keadaan sehat dapat dijadikan data dasar sebagai pembanding suatu penelitian yang menjadikan limpa sebagai parameternya. Pertahanan tubuh kelelawar terhadap agen infeksius telah diketahui berdampak pada terjadinya stres oksidatif, sebagaimana hasil penelitian yang dilaporkan oleh Schneeberger et al. (2013) yang menginfeksi kelelawar liar dengan lipopolisakarida bakteri. Kelelawar sebagai reservoir virus dan hewan yang dapat terbang diduga dapat menghasilkan reactive oxygen species (ROS) yang tinggi berkaitan dengan respons kekebalan seluler dan tingginya laju metabolisme. ROS merupakan radikal bebas yang diproduksi setiap makhluk hidup dalam metabolime normal. Organ limfoid 
termasuk limpa diduga dapat mengakumulasi ROS dalam jumlah tinggi yang berdampak pada respons kekebalannya dan menyebabkan kondisi stres oksidatif. Stres oksidatif dapat mengakibatkan perubahan struktur DNA, aktivasi beberapa faktor transkripsi, serta produksi sitokin proinflamasi dan antiinflamasi.Senyawa ROS dapat menyebabkan reaksi peroksidasi rantai lemak sehingga terbentuk produk sekunder malonaldehyde (MDA). Keseimbangan status redoks antara radikal bebas dan antioksidan sangat penting untuk mencegah pelonjakan tingkat stres oksidatif (Birben et al., 2012). Terdapat fakta menarik bahwa kelelawar dilaporkan memiliki kadar antioksidan yang tinggi dibandingkan manusia dan primata (Filho et al., 2007) sehingga kajian status stres oksidatif pada organ limpa sangat menarik untuk dilakukan. Salah satu antioksidan endogen utama adalah superoxide dismutase (SOD). Keseimbangan redoks antara radikal bebas dan antioksidan endogen limpa kelelawar pemakan buah yang menentukan status stres oksidatif serta kaitannya dengan morfologi dan fisiologi kekebalannya perlu diketahui untuk pemahaman mendalam mengenai fisiologi limpa kelelawar dan status kekebalannya.

Penelitian ini dilakukan untuk menganalisis dan mendokumentasikan ukuran (panjang, lebar, tebal, luas, dan bobot) limpa kelelawar pemakan buah (Cynopterus sp.) serta menganalisis dan mengaji kadar radikal bebas (MDA) dan antioksidan (SOD) organ limpa kelelawar pemakan buah untuk menentukan status stres oksidatif yang dikaitkan dengan morfologi limpa secara makroskopis dan fisiologi kekebalannya. Hasil penelitian ini diharapkan dapat menjadi informasi baru terkait morfofisiologi organ kekebalan kelelawar pemakan buah codot krawar (C. brachyotis) khususnya limpa. Informasi mengenai morfofisiologi limpa nantinya diperlukan untuk membantu dalam menentukan status kekebalan kelelawar dan dapat menjadi data dasar dalam penelitian eksperimental yang menggunakan kelelawar.

\section{METODE PENELITIAN}

Penelitian dilaksanakan dari bulan September 2016 hingga April 2017 di Laboratorium Anatomi dan Fisiologi, Departemen Anatomi Fisiologi dan Farmakologi, Fakultas Kedokteran Hewan IPB.
Penangkapan Kelelawar dan Aklimatisasi. Kelelawar pemakan buah C. brachyotis dewasa (tiga ekor jantan dan empat ekor betina) ditangkap di dalam area Institut Pertanian Bogor (IPB), di Dramaga, Bogor, Jawa Barat pada malam hari dengan menggunakan jaring kabut. Kelelawar yang ditangkap, dimasukkan ke dalam kandang dan dibawa ke laboratorium untuk aklimatisasi kondisi fisiologis kelelawar. Aklimatisasi dilakukan selama 24 jam dengan pemberian pakan berupa potongan buah dan air minum ad libitum.

Pemeriksaan Status Kesehatan. Kelelawar pemakan buah dikendalikan dengan memegang bagian leher dan sayapnya. Operator menggunakan sarung tangan yang cukup tebal untuk menghindari gigitan. Kelelawar diperiksa status kesehatannya dengan mengamati perilakunya di dalam kandang, adanya perlukaan di permukaan tubuh, dan aspek permukaan mukosa.

Pembiusan. Kelelawar dianestesi dengan injeksi ketamine (dosis $10 \mathrm{mg} / \mathrm{kg}$ bobot badan) dan xylazine ( $2 \mathrm{mg} / \mathrm{kg}$ bobot badan) (Sohayati $e t$ al., 2008). Kelelawar yang telah teranestesi dengan baik, ditimbang bobot badannya dengan menggunakan timbangan digital.

Identifikasi Spesies dan Pengelompokkan Kelelawar. Kelelawar pemakan buah diidentifikasi untuk mengetahui spesiesnya. Identifikasi dilakukan dengan pengukuran terhadap panjang humerus, panjang tibia, panjang tubuh, panjang tarsal sampai digit, panjang bentang sayap, dan keberadaan tonjolan kunyah pada gigi. Kunci identifikasi mengacu pada Panduan Lapangan Kelelawar Indonesia (Suyanto 2001). Kelelawar yang ditangkap dikelompokkan berdasarkan spesies dan jenis kelamin. Kelelawar yang ditangkap dipastikan telah dewasa kelamin yang ditandai dengan turunnya testis pada jantan dan pembukaan vagina pada betina.

Pengambilan Data Sampel Limpa. Kelelawar dibaringkan dengan menengadahkannya (secara dorsal recumbency) di atas styrofoam dengan memfiksir bagian sayap proximal dan distal menggunakan jarum pentul. Pembedahan laparotomi dilakukan dari ventral sehingga rongga perut terbuka. Limpa kelelawar diambil dengan mempreparir serosa dan pembuluh darah lienalis. Pengukuran terhadap bobot, panjang, lebar, tebal, luas, dan volume juga dilakukan. Pengukuran bobot limpa dilakukan dengan timbangan digital. Pengukuran panjang, lebar, dan tebal dilakukan dengan 
menggunakan jangka sorong. Pengu-kuran luas dilakukan dengan mengalikan panjang dan lebar limpa. Hasil pengukuran limpa berupa bobot, panjang, lebar, tebal, dan luas setiap ekor kelelawar dicari rataannya dan dikelompokkan berdasarkan jenis kelamin. Rasio bobot limpa terhadap bobot badan juga dihitung.

Pengukuran Kadar MDA dan SOD. Sampel limpa dari setiap individu kelelawar dibagi dua untuk pengukuran kadar MDA dan SOD. Masing-masing bagian ditimbang dan dicatat bobotnya dalam satuan mili gram kemudian dicacah hingga halus. Cacahan limpa untuk pengukuran MDA dilarutkan dalam 1 mL larutan PBS-KCl pH 7,4 sedangkan untuk pengukuran SOD dilarutkan dalam $1 \mathrm{~mL}$ larutan PBS pH 7,4. Cacahan limpa dalam larutan PBS disentrifuse pada kecepatan 10.000 rpm selama 20 menit dalam suhu $2-4^{\circ} \mathrm{C}$ dalam sentrifuge (Sorvall ${ }^{\circledR}$ RC 5B Plus). Supernatan yang diperoleh dari hasil sentrifuse disimpan pada suhu $-20^{\circ} \mathrm{C}$ sebelum dianalisis dengan spektrofotometri (Hitachi ${ }^{\circledR}$ U-2001). Analisis spektrofotometri MDA dilakukan dengan panjang gelombang $532 \mathrm{~nm}$ sedangkan SOD dengan panjang gelombang $480 \mathrm{~nm}$.

\section{Analisis Data}

Semua hasil pengamatan yang diperoleh dianalisis secara deskriptif dan disajikan dalam bentuk tabel.

\section{HASIL DAN PEMBAHASAN}

\section{Identifikasi Spesies Kelelawar}

Kelelawar pemakan buah yang ditangkap dan kemudian diidentifikasi berdasarkan Panduan Lapangan Kelelawar Indonesia (Suyanto 2001) merupakan codot krawar atau spesies C. brachyotis. Kelelawar dinyatakan dalam kondisi sehat yang ditandai dengan kondisi segar bugar (fit) dan tidak lemas, tidak adanya perlukaan di permukaan tubuh, dan aspek permukaan mukosa yang baik. Kelelawar C. brachyotis (codot krawar) merupakan kelelawar suku Cynopterinae yang termasuk dalam keluarga pemakan tumbuhan, Pteropodidae. Spesies ini tersebar secara luas dari Asia Selatan menyebar di sebagian daerah di selatan Tiongkok dan sebagian Asia Tenggara. Kelelawar C. brachyotis dapat ditemukan di berbagai habitat seperti perkebunan hingga hutan (Csorba et al., 2008). Kelelawar ini bersarang sendiri atau berkelompok kecil di area sekitar pemukiman penduduk. Kelelawar $C$. brachyotis secara umum adalah pemakan buah (frugivora) namun dilaporkan juga memakan nektar (Campbell et al., 2007).

\section{Ukuran Limpa serta Rasio Bobot Limpa terhadap Bobot Badan}

Pengetahuan terhadap ukuran limpa suatu spesies dalam keadaan sehat dapat dijadikan data dasar sebagai pembanding suatu penelitian yang menjadikan limpa sebagai parameternya. Bobot limpa C.brachyotis pada penelitian ini dibandingkan dengan bobot badannya sehingga diperoleh data dalam persentase yang dapat dibandingkan dengan individu lainnya. Perbedaan bobot badan dan bobot limpa jantan dan betina pada penelitian ini tidak berbeda secara signifikan. Bobot badan kelelawar yang diamati berkisar antara 29-36 g dengan rataan bobot badan jantan lebih berat daripada betina yaitu $35,07 \pm 2,08 \mathrm{~g}$ untuk tiga ekor jantan dan $31,07 \pm 2,54 \mathrm{~g}$ untuk empat ekor betina. Rasio bobot limpa dibandingkan bobot tubuh kelelawar jantan juga sedikit lebih besar dibandingkan betina (jantan 0,43 $\pm 0,04 \%$; betina $0,35 \pm 0,20 \%$ ) namun tidak berbeda secara signifikan. Rataan keseluruhan rasio bobot limpa terhadap bobot badan $C$. brachyotis yang dianalisis adalah sebesar 0,4\%. Rasio bobot limpa dibandingkan bobot tubuh hewan lain yang telah didokumentasikan antara lain tikus sebesar 0,20,3\% (Losco 1992) dan mencit sebesar 0,7\% (Webster dan Liljegren, 1955). Nilai rasio bobot limpa terhadap bobot badan C.brachyotis lebih besar atau hampir sama dengan nilai rasio tikus namun lebih kecil dari mencit. Pengukuran terhadap panjang, lebar, dan tebal limpa berturut-turut menghasilkan rataan data sebagai berikut: $1,44 \pm 0,23 \mathrm{~mm} ; 0,46 \pm 0,07$ $\mathrm{mm}$; dan 0,22 $\pm 0,09 \mathrm{~mm}$ pada kelelawar jantan, serta $1,53 \pm 0,07 \mathrm{~mm} ; 0,38 \pm 0,08 \mathrm{~mm} ; 0,24 \pm$ 0,06 pada kelelawar betina. Berdasarkan data yang diperoleh, rataan luas limpa jantan sedikit lebih besar daripada betina yaitu $0,66 \pm 0,14 \mathrm{~mm}^{2}$ dan $0,57 \pm 0,10 \mathrm{~mm}^{2}$ untuk jantan dan betina namun tidak berbeda secara signifikan. Data yang diperoleh dirangkum pada Tabel 1.

Limpa merupakan organ limfoid terbesar dan berperan penting dalam fisiologi tubuh. Organ limpa mencakup tiga sistem di dalamnya yaitu sistem monosit makrofag, sistem limfatik, dan sistem pembuluh darah. Parenkim limpa secara mikroskopis terdiri dari pulpa merah dan pulpa putih. Pulpa merah berperan penting pada pembersihan partikel asing dalam darah 
Tabel 1.Hasil pengukuran bobot badan dan limpa kelelawar pemakan buah C. brachyotis.

\begin{tabular}{|c|c|c|c|c|c|c|c|c|}
\hline Jenis Kelamin & $\mathrm{N}$ & $\begin{array}{l}\text { Bobot } \\
\text { Badan } \\
\text { (g) }\end{array}$ & $\begin{array}{l}\text { Bobot } \\
\text { Limpa } \\
\text { (g) }\end{array}$ & $\begin{array}{l}\text { Rasio } \\
\text { BL:BB* } \\
(\%)\end{array}$ & $\begin{array}{l}\text { Panjang } \\
\text { Limpa } \\
(\mathrm{mm})\end{array}$ & $\begin{array}{l}\text { Lebar } \\
\text { Limpa } \\
(\mathrm{mm})\end{array}$ & $\begin{array}{l}\text { Tebal } \\
\text { Limpa } \\
(\mathrm{mm})\end{array}$ & $\begin{array}{l}\text { Luas } \\
\text { Limpa } \\
\left(\mathrm{mm}^{-2}\right)\end{array}$ \\
\hline Jantan & 3 & $\begin{array}{l}35,07 \pm \\
2,08\end{array}$ & $\begin{array}{l}0,15 \pm \\
0,02\end{array}$ & $\begin{array}{l}0,43 \pm \\
0,04\end{array}$ & $\begin{array}{l}1,44 \pm \\
0,23\end{array}$ & $\begin{array}{l}0,46 \pm \\
0,07\end{array}$ & $\begin{array}{l}0,22 \pm \\
0,09\end{array}$ & $\begin{array}{l}0,66 \pm \\
0,14\end{array}$ \\
\hline Betina & 4 & $\begin{array}{l}31,07 \pm \\
2,54\end{array}$ & $\begin{array}{l}0,11 \pm \\
0,06\end{array}$ & $\begin{array}{l}0,35 \pm \\
0,20\end{array}$ & $\begin{array}{l}1,53 \pm \\
0,07\end{array}$ & $\begin{array}{l}0,38 \pm \\
0,08\end{array}$ & $\begin{array}{l}0,24 \pm \\
0,06\end{array}$ & $\begin{array}{l}0,57 \pm \\
0,10\end{array}$ \\
\hline
\end{tabular}

*)Keterangan : $\mathrm{BL}=$ Bobot Limpa; BB= Bobot Badan

via fagosit oleh makrofag, penyimpanan eritrosit matang, dan hematopoiesis pada beberapa kondisi. Pulpa putih merupakan folikel-folikel limfoid yang berperan dalam aktivasi limfositT dan B serta sel-sel imunokompeten lainnya (Fry dan McGavin, 2007; Brendolan et al., 2007).

Standar ukuran limpa pada suatu spesies di dalam populasi dipengaruhi secara epigenetik oleh lingkungan dan keberagaman parasit yang menginfeksinya (Morand dan Poulin, 2000; Ardia 2005). Hewan yang hidup dalam populasi berdensitas tinggi memiliki limpa yang lebih besar akibat adanya penyebaran infeksi parasit dalam satu populasi (Møller et al., 1993; Møller et al., 2001). Individu yang mengalami seleksi alam lebih keras dengan risiko paparan ektoparasit dan endoparasit tertinggi memiliki ukuran limpa yang relatif besar untuk ukuran tubuhnya (Møller dan Erritzoe, 2002). Keberagaman spesies parasit pada suatu spesies inang juga berperan besar pada evolusi ukuran limpa spesies tersebut (Morand dan Poulin, 2000; Brown dan Brown, 2002). Kelelawar secara umum memiliki masa hidup panjang dibandingkan mamalia darat yang seukuran dengannya (South dan Wilkinson, 2009). Hewan dengan masa hidup panjang memiliki kesempatan terinfeksi parasit dengan keragaman tinggi dalam jangka waktu panjang (Poulin 1995), sehingga jika dikaitkan dengan teori sebelumnya maka ukuran limpanya juga relatif besar terhadap ukuran tubuhnya. Kelelawar C. brachyotis dalam penelitan ini memiliki ukuran limpa yang berukuran tidak terlalu besar relatif dengan ukuran tubuhnya yaitu berukuran mirip dengan tikus namun lebih kecil dari mencit. Kelelawar C. brachyotis pada penelitian ini ditangkap di daerah pemukiman penduduk seringkali ditemukan bersarang sendiri atau tidak berkoloni dalam jumlah besar sehingga berisiko kecil mengalami paparan penularan parasit inter-antar spesies yang menyebabkan ukuran limpa tidak terlalu besar dibandingkan hewan seukurannya. Penelitian lebih lanjut mengenai keragaman parasit yang menginfeksi kelelawar $C$. brachyotis perlu dilakukan untuk memastikan hipotesis tersebut.

Ukuran limpa juga dapat berubah secara dinamis yang tidak hanya dipengaruhi oleh aktivitas sel-sel kekebalan namun juga dipengaruhi oleh aktivitas fisiologis lain yang berlangsung di dalamnya. Fungsi fisiologis limpa berbeda antar spesies bergantung pada sel-sel dan jaringan penyusunnya. Limpa mamalia secara umum memiliki fungsi reservoir darah dan hematopoiesis, sehingga perubahan ukuran limpa tidak dapat secara langsung diinterpretasikan sebagai peningkatan aktivitas kekebalan (Nunn 2002). Arsitektur sel-sel penyusun limpa menentukan fungsi fisiologis limpa mamalia sehingga dapat diklasifikasikan menjadi tipe penyimpan, tipe pertahanan, dan intermediet. Limpa tipe penyimpan atau reservoir darah diidentifikasi pada kucing dan anjing, tipe pertahanan diidentifikasi pada manusia, mencit, dan tikus, sedangkan tipe intermediet diidentifikasi pada ruminansia dan babi (Haley 2003). Morfologi sel-sel penyusun limpa kelelawar belum pernah didokumentasi hingga saat ini sehingga fungsi fisiologisnya belum diketahui dan perbandingan fungsi fisiologinya dengan spesies lain memerlukan penelitian lebih lanjut.

Kondisi patologi pada individu juga dapat berpengaruh secara langsung pada ukuran limpa. Ukuran limpa yang membesar merupakan imbas dari meningkatnya massa parenkim dan volume limpa. Kondisi patologis yang paling sering menyebabkan meningkatnya ukuran limpa yaitu peningkatan volume darah (kongesti), peningkatan sel sistem monosit makrofag, hiperplasia limfoid, peradangan, dan neoplasia (Fry dan McGavin, 2007). Sebaliknya, 
ukuran limpa yang mengecil merupakan indikasi terjadinya hipofungsi limpa akibat dari kanker pada organ lain, neoplasma darah, dan penyakit autoimun (Sabatino et al., 2013).

\section{Analisis Kadar ROS}

Analisis ROS pada limpa kelelawar dalam penelitian ini dilakukan dengan indikator kadar MDA dan dibandingkan dengan organ hati. Nilai MDA limpa C. brachyotis secara umum jauh lebih besar daripada nilai MDA hati (Tabel 2). Hati merupakan organ utama yang menghasilkan ROS yang tinggi dan menjadi organ yang seringkali terpapar dampak stres oksidatif terbesar (Birben et al., 2012) sehingga nilai MDA limpa yang lebih tinggi daripada hati menjadi temuan yang unik pada suatu individu. Organ limpa di sisi lain juga merupakan organ yang berpotensi menghasilkan ROS tinggi karena berperan dalam pertahanan patogen bloodborne.

Organ-organ interna selama aktivitas fisik akan mengalami hipoksia dan iskemia karena oksigen secara umum terdistribusi ke otot yang bekerja. Tubuh kelelawar, sebagai reservoir virus dan hewan yang dapat terbang, menghasilkan radikal bebas atau ROS yang tinggi berkaitan dengan respons kekebalan seluler dan tingginya laju metabolisme. Metabolisme makhluk hidup dalam keadaan fisiologis menghasilkan ROS sebagai produk sampingannya. Konsentrasi ROS dalam jumlah rendah sampai sedang memiliki peran dalam proses fisiologis sel, namun pada konsentrasi tinggi ROS dapat menyebabkan stres oksidatif dan bermanifestasi pada kerusakan pada beberapa komponen seperti lipid, protein, dan DNA serta seringkali berujung pada terjadinya kanker dan penyakit degeneratif (Buffeinstein 2008; Birben et al., 2012; Zuo et al., 2015).

Kebutuhan energi tinggi saat kelelawar terbang, meningkatkan konversi Adenosin Triphosphate (ATP) menjadi Adenosin Dipho- sphate (ADP) dan Adenosin Monophospate (AMP). Kondisi hipoksia pada jaringan akan meningkatkan konversi AMP menjadi hipoxantin. Aliran darah akan kembali normal setelah aktivitas fisik yang tinggi selesai melalui proses reperfusi. Proses reperfusi akan mengubah hipoxantin menjadi xantin dan asam urat. Proses ini akan menghasilkan radikal bebas yang dapat merusak membran melalui peroksidasi lipid (Candrawati 2013). Senyawa MDA merupakan hasil dekomposisi hidroperoksida lipid yang berasal dari lipid yang bereaksi dengan radikal bebas (Birben et al., 2012), sehingga tingginya nilai MDA menandakan tingginya produksi radikal bebas.

Reactive Oxygen Species diketahui memberikan dampak negatif melalui kerusakan oksidatif, namun tingginya ROS dalam limpa C. brachyotis dapat memberikan keuntungan terhadap sistem pertahanan tubuh berkaitan dengan peran limpa sebagai pertahanan patogen blood borne dan kelelawar sebagai reservoir virus. Yang et al. (2012) merangkum peran penting ROS dalam sistem imunitas yaitu: (1) berperan pada pensinyalan sel sebagai second messengers dan mengaktivasi sel-sel kekebalan; (2) merupakan senjata sel fagosit melawan mikroorganisme yang disebut sebagai respiratory burst atau oxidative burst; (3) berperan dalam surveilance imunitas dan pengenalan antigen oleh pattern recognition receptors (PRR); (4) berperan dalam aktivitas antibakteri dan antivirus serta aktivasi pensinyalan untuk respons imunitas spesifik; (5) berperan dalam sitolisis sel oleh sel natural killer (NK); (6) merangsang diferensiasi sel dendrit dari sel hematopoietik; (7) aktivasi sel T dengan stimulasi reseptor sel T dan meregulasi apoptosis sel $\mathrm{T}$; (8) berperan dalam aktivasi dan pensinyalan sel B; serta (9) berperan dalam supresi yang dimediasi sel $\mathrm{T}$ regulator dalam diferensiasi sitokin peradangan dan menurunkan reaksi peradangan berlebihan. Tingginya kadar ROS

Tabel 2. Kadar superoxide dismutase (SOD) dan malonaldehyde (MDA) organ limpa dibandingkan organ hati kelelawar pemakan buah C. brachyotis.

\begin{tabular}{lcccccc}
\hline \multirow{2}{*}{ Jenis Kelamin } & $\mathrm{N}$ & $\begin{array}{c}\text { Rasio } \\
\text { BL:BB* }(\%)\end{array}$ & \multicolumn{2}{c}{ Limpa } & \multicolumn{2}{c}{ Hati } \\
\cline { 4 - 7 } & & & $\begin{array}{c}\text { MDA } \\
\left(\mathrm{gr}^{-1} \text {.sampel }\right)\end{array}$ & $\begin{array}{c}\text { SOD } \\
\left(\mathrm{gr}^{-1} \cdot \text { sampel }\right)\end{array}$ & $\begin{array}{c}\text { MDA } \\
\left(\mathrm{gr}^{-1} \cdot \text {.sampel }\right)\end{array}$ & $\begin{array}{c}\text { SOD } \\
\left(\mathrm{gr}^{-1} \cdot \text { sampel }\right)\end{array}$ \\
\hline Jantan & 3 & $0,43 \pm 0,04$ & $29,62 \pm 15,64$ & $55,56 \pm 26,79$ & $1,68 \pm 0,82$ & $5,72 \pm 0,73$ \\
Betina & 4 & $0,35 \pm 0,20$ & $14,34 \pm 5,25$ & $37,13 \pm 15,26$ & $5,30 \pm 3,75$ & $7,96 \pm 0,47$ \\
\hline
\end{tabular}

*)Keterangan : BL= Bobot Limpa; BB= Bobot Badan 
dalam limpa C. brachyotis dapat mengindikasikan adanya aktivitas kekebalan yang tinggi di dalam limpa.

Kelelawar yang digunakan dalam penelitian ini adalah kelelawar liar yang ditangkap langsung dari alam yang secara fisik sehat dan dalam keadaan aktif, namun status infeksi yang dibawanya tidak diketahui.Penelitian yang telah dilakukan oleh Gomez et al. (2016) menyatakan bahwa limpa kelelawar P. alecto didominasi oleh $\mathrm{CD}^{+}$sel $\mathrm{T}$ dibandingkan $\mathrm{CD} 4^{+}$sel $\mathrm{T}$ dalam keadaan belum mengenal virus. $\mathrm{CD}^{+}$sel $\mathrm{T}$ naïve memiliki kapasitas untuk mengenali patogen dengan ekspansi yang masif dan berdiferensiasi menjadi sel sitotoksik yang bermigrasi ke seluruh bagian tubuh untuk mengatasi infeksi (Zhang dan Bevan, 2011). Sel $\mathrm{T}$ sitotoksik $\mathrm{CD} 8^{+}$menghasilkan molekul sitolitik seperti granzymes dan perforin yang dapat melisiskan sel secara langsung sehingga sel ini memiliki peran strategis untuk perlawanan patogen intraselular termasuk virus (Lier et al., 2003). Kondisi populasi $\mathrm{CD} 8^{+}$sel T yang tinggi pada limpa kelelawar diduga merupakan bentuk kesiagaan pertahanan tubuh kelelawar dalam melawan infeksi virus (Gomez et al., 2016). Tingginya kadar ROS dalam penelitian ini mendukung dugaan tersebut yang mengindikasikan adanya aktivitas kekebalan yang tinggi dalam limpa kelelawar akibat kesiapannya dalam menerima infeksi. Aktivitas kekebalan yang tinggi secara teori dapat meningkatkan ukuran limpa yang juga didukung oleh lebih besarnya ukuran limpa pada hewan jantan yang memiliki kadar MDA dibandingkan hewan betina pada penelitian ini.

\section{Analisis Kadar SOD}

Analisis kadar SOD limpa C. brachyotis dilakukan dalam penelitian ini untuk mengetahui aktivitas antioksidan di dalamnya. Senyawa SOD merupakan enzim intraseluler yang berperan dalam degradasi senyawa radikal bebas atau ROS utama yaitu super oksida (Wresdiyati et al., 2007; Birben et al., 2012). Sejalan dengan tingginya kadar MDA pada limpa C. brachyotis, kadar SOD limpa juga jauh lebih tinggi dibandingkan dengan kadar SOD pada organ hati (Tabel 2). Vertebrata secara umum menghasilkan antioksidan untuk menetralisir radikal bebas yang terbentuk untuk menjaga homeostasis tubuh (Birben et $a l ., 2012)$. Kelelawar telah diketahui memiliki aktivitas SOD yang lebih tinggi dibandingkan manusia dan primata dengan kadar SOD tertinggi di dalam darah, hati, dan ginjal (Filho et al., 2006), sedangkan limpa C. brachyotis dalam penelitian ini memiliki kadar SOD lebih besar dari hati. Kadar SOD yang tinggi diperkirakan mengikuti tingginya kadar MDA, karena pada saat terjadi stres oksidatif, sel akan berusaha mengantisipasi kerusakan dengan menghasilkan oksidan dan mengembalikan keseimbangan redoks (Birben et al., 2012). Kadar SOD dalam limpa kelelawar dua kali lebih besar dari kadar MDA, sehingga diperkirakan antioksidan endogen mampu mengimbangi dan menetralisir produksi radikal bebas yang tinggi dalam limpa dan mencegah kerusakan oksidatif.

\section{SIMPULAN}

Kelelawar C. brachyotis memiliki rasio bobot limpa dibandingkan bobot badan sebesar $0,4 \%$ dan relatif tidak beda antara jantan dan betina. Kadar MDA dalam organ limpa C. brachyotis lebih tinggi daripada organ hati. Rataan ukuran limpa yang lebih besar memiliki rataan kadar MDA yang lebih tinggi. Kadar MDA yang tinggi dalam limpa juga disertai dengan kadar SOD yang tinggi.

\section{SARAN}

Penelitian terhadap keberagaman ektoparasit dan endoparasit $C$. brachyotis perlu dilakukan untuk memastikan pengaruhnya terhadap ukuran limpa. Kajian mendalam terhadap morfologi makroskopis dan mikroskopis limpa dan organ limfoid kelelawar secara umum termasuk sel dan jaringan penyusunnya perlu dilakukan lebih lanjut untuk dapat memahami fisiologi organ kekebalan kelelawar termasuk limpa secara keseluruhan.

\section{UCAPAN TERIMA KASIH}

Terima kasih penulis sampaikan kepada Kementrian Riset Teknologi dan Pendidikan Tinggi atas bantuan pendanaan berdasarkan Surat Perjanjian Penugasan Program Penelitian Tahun Anggaran 2016 Nomor: 330/SP2H/LT/ DRPM/IX.2016 tanggal 8 September 2016 dalam program Beasiswa Pendidikan Magister Menuju Doktor untuk Sarjana Unggul (PMDSU) Batch II. 


\section{DAFTAR PUSTAKA}

Ardia DR. 2005. Cross-fostering reveals an effect of spleen size and nest temperatures on immune responses in nestling Europian starling. Oecologia 145: 327-334.

Baker ML, Schountz T, Wang LF. 2012. Antiviral immune response of bats: A review. Zoonoses Public Hlth 60: 104-115.

Bhatnagar PS. 2013. A Classified list of Megachiroptera in South-East Asia. Malay Nat J 65(2): 22-29.

Birben E, Sahiner UM, Sackesen C, Erzurum S, Kalayci O. 2012. Oxidative stress and antioxidant defense. WAO: 9-19.

Brendolan A, Rosado MM, Carsetti R, Selleri L, Dear TN. 2007. Development and function of the mammalian spleen. BioEssays 29: 166-177.

Bronte V, Pittet M. 2013. The spleen in local and systemic regulation of immunity. Immunity 39: 806-818

Brown CR, Brown MB.2002. Spleen volume varies with colony size and parasite load in a colonial bird. Proc $R$ Soc Lond $B$ 269: 1367-1373

Buffeinstein R, Edrey YH, Yang T, Mele J. 2006. The oxidative theory of aging: embattled or invincible? Insight from non-traditional model organisms. Age 30: 99-109.

Calisher CH, Childs JE, Field HE, Holmes KV, Schountz T. 2006. Bats: Important Reservoir Hosts of Emerging Viruses. Clin Microbiol Rev 19(3): 531-545.

Campbell P, Schneider CJ, Zubaid A, Adnan AM, Kunz TH. 2007. Morphological and ecological correlates of coexistence in malaysian fruit bats (Chiroptera: Pteropodidae). J Mammal 88(1): 105-118.

Candrawati S. 2013. Pengaruh aktivitas fisik terhadap stres oksidatif. Mandala of Health 6(1): 454-461.

Csorba G, Bumrungsri S, Francis C, Bates P, Gumal M, Kingston T, Molur S, Srinivasulu C. 2008. Cynopterus brachyotis. The IUCN Red List of Threatened Species 2008: e.T6103A12432460. [Internet]. [Diacu 2017 April 8]. Tersedia dari: http://dx.doi.org/ 10.2305 / I U C N. U K. 2008 . R L T S . T6103A12432460.en.
Damayanti NLPI, Sendow I. 2015. Ebola: Penyakit eksotik zoonosis yang perlu diwaspadai. Wartazoa 25(1): 29-38.

Dobson AP. 2005. What links bats to emerging infectious diseases?. Science 310: 628-629.

Filho DW, Althoff SL, Dafre AL, Boveris A. 2007. Antioxidant defenses, longevity and ecophysiology of South American bats. Comp Biochem Physiol 146: 214-220.

Fry ME, McGavin MD. 2007. Bone Marrow, blood cells, and lymphatic system. Dalam: McGavin MD, Zachary JF. (Eds). Pathologic Basis of Veterinary Disease $4^{\text {th }}$ Edition. Missouri: Mosby Elsevier.

Gomez JM, Periasamy P, Dutertre CA, Irving AT, Ng JHJ, Crameri G, Baker ML, Ginhoux F, Wang LF, Alonso S. 2016. Phenotypic and functional characterization of the major lymphocyte populations in the fruit-eating bat Pteropus alecto. Nature 6(37796): 1-13

Haley PJ. 2003. Species differences in the structure and function of the immune system. Toxicology 188: 49-71.

Han HJ, Wen HL, Zhou CM, Chen FF, Luo LM, Liu JW, Yu XJ. 2015. Bats as reservoir of severe emerging infectious diseases. Virus Research 205: 1-6.

Lier RA, Berge IJM, Gamadia LE. 2003. Human CD8 ${ }^{+}$T-Cell differentiation in response to viruses. Nature Reviews 3: 1-8

Losco P. 1992. Normal Development, Growth, and Aging of the Spleen. Dalam Mohr U, Dungworth, Dh Capen CC. (Eds) Pathobiology of Aging Rat. Vol I. Washington DC. ILSI Press. Hlm.75-94.

Luis AD, Hayman DTS, O'Shea TJ, Cryan PM, Gilbert AT, Pulliam JR, Mills JN, Timonin ME, Willis CKR, Cunningham AA, Fooks AR, Rupprecht CE, Wood JLN, Webb CT. 2013. A comparison of bats and rodents as reservoirs of zoonotic viruses: Are bats special? Proc $R$ Soc B 280: 1-9.

Messengger SL, Smith JS, Rupprecht CE. 2002. Emerging Epidemiology of Bat-Associated Cryptic Cases of Rabies in Humans in the United States. Clin Infect Dis 35: 738-747.

Møller AP, Dufva R, Allander K. 1993. Parasites and the evolution of host social behavior. Adv St Behav 22: 65-102. 
Møller AP, Merino S, Brown C, Robertson RJ. 2001. Immune defense and host sociality: a comparative study of swallows and martins. Am Nat 158: 136-145.

Møller AP, Erritzoe J. 2002. Coevolution of host immune defence and parasite-induced mortality: relative spleen size and mortality in altricial birds. Oikos 99: 95-100.

Morand S, Poulin R. 2000. Nematode parasite species richness and the evolution of spleen size in birds. Can $J$ Zoo 78: 1356-1360.

Nunn CL. 2002. Spleen size, disease risk and sexual selection: A comparative study in primates. Evol Ecol Res 4: 91-107.

O'Shea TJ, Cryan PM, Cunningham AA, Fooks AR, Hayman DTS, Luis AD, Peel AJ, Plowright RK, Wood JLN. 2014. Bat flight and zoonotic viruses. Emerg infect diseases 20(5): 741-745.

Poulin R. 1995. Phylogeny, ecology, and the richness of parasite communities in vertebrates. Ecol Appl 65(3): 283-302.

Sabatino AD, Maffe GC, Brunetti L, Guerci M, Corazza GR. 2013. Splenic hypofunction in patients with an incidental finding of smallsized spleen at abdominal ultrasound. Intern Emerg Med 8: 361-362.

Schneeberger K, Czirjak GGA, Volgt CC. 2013. Inflammatory challenge increases measures of oxidative stress in free-ranging long-lived mammal. J Exp Biol 216: 4514-4519.

Schountz T. 2014. Immunology of bats and their viruses: Challenges and opportunities. Viruses 6: 4880-4901.

Smith I, Wang LF. 2013. Bats and their virome: An important source of emerging viruses capable of infecting humans. Curr Opin Virol 3: 84-91.
Sohayati AR, Zaini CM, Hassan L, Epstein J,Suri S, Daszak P, Sharifah SH. 2008. Ketamine and xylazine combinations for short-term immobilization of wild variable flying foxes (Pteropus hypomelanus). J Zoo Widl Med 39(4): 674-676.

South JM, Wilkinson GS. 2009. Bats and birds: Exceptional longevity despite high metabolic rates. Ageing Res Rev 237: 1-8.

Suyanto A. 2001. LIPI-Seri Panduan Lapangan; Kelelawar di Indonesia. Bogor: Puslitbang Biologi-LIPI.

Webster SH, Liljegren EJ. 1955. Organ: Bodyweight ratios for certain organs of laboratory animals. III. White Swiss mouse. Dev Dyn 97(1): 129-153.

Wresdiyati T, Astawan M, Fithriani D, Adnyane IKM, Novelina S, Aryani S. 2007. Pengaruh á-tokoferol terhadap profil superoksida dismutasi dan malonaldehida pada jaringan hati tikus di bawah kondisi stres. $J$ Veteriner 202-209.

Yang Y, Bazhin AV, Werner J, Karakhanova S. 2012. Reactive Oxygen Species in the Immune System. Int Rev Immunol 1-22.

Zhang N, Bevan MJ. 2011. CD8 ${ }^{+}$T cells: Foot soldiers of the immune system. Immunity 35(2): 161-168.

Zuo L, Zhou T, Pannell BK, Ziegler AC, Best TM. 2015. Biological and physiological role of reactive oxygen species- the good, the bad, and the ugly. Acta Physiol. 214: 329-348. 